(C) The Author(s), 2021. Published by Cambridge University Press on behalf of the Arizona Board of Regents on behalf of the University of Arizona. This is an Open Access article, distributed under the terms of the Creative Commons Attribution licence (http://creativecommons.org/licenses/by/4.0/), which permits unrestricted re-use, distribution, and reproduction in any medium, provided the original work is properly cited.

\title{
THE TEMPO OF CULTURAL CHANGE IN THE KOSTENKI UPPER PALEOLITHIC: FURTHER INSIGHTS
}

Rob Dinnis ${ }^{1 *}$ (D) Alexander A Bessudnov ${ }^{2} \cdot$ Natasha Reynolds $^{3} \cdot$ Gennady A Khlopachev ${ }^{4}$ - Mikhail Sablin ${ }^{5}$ - Andrei Sinitsyn ${ }^{2}$ - Thomas Higham ${ }^{6}$ • Katerina Douka ${ }^{7}$

\footnotetext{
${ }^{1}$ Department of Archaeology, University of Aberdeen, St Mary's Building, Elphinstone Road, Aberdeen, AB24 3UF, UK ${ }^{2}$ Institute for the History of Material Culture, Russian Academy of Sciences, Dvortsovaia Naberezhnaia 18, Saint Petersburg, 191186, Russia

${ }^{3}$ UMR 5199 PACEA, Université de Bordeaux, Bâtiment B8, Allée Geoffroy Saint Hilaire, CS 50023, Pessac Cedex, 33615, France

${ }^{4}$ Museum of Anthropology and Ethnography, Russian Academy of Sciences (Kunstkamera), Universitetskaya Naberezhnaia 3, Saint Petersburg, 199034, Russia

${ }^{5}$ Zoological Institute, Russian Academy of Sciences, Universitetskaya Nab. 1, Saint Petersburg, 199034, Russia ${ }^{6}$ Oxford Radiocarbon Accelerator Unit, RLAHA, South Parks Road, University of Oxford, Oxford, OX1 3QY, UK

${ }^{7}$ Max Planck Institute for the Science of Human History, Jena, Germany
}

\begin{abstract}
The Kostenki-Borshchevo site complex (Voronezh region, Russia) serves as the foundation of Eastern Europe's Upper Paleolithic chronocultural framework. Here we present new radiocarbon dates for three Kostenki sites. Dates of $27.5-27$ ka BP for Kostenki 15 suggest that its archaeological layer accumulated over a short period. These results help to confirm that the site is unrelated to Aurignacian assemblages. New dates for the Kostenki-Avdeevo Culture (KAC) Layer I of Kostenki 1 address the longstanding question of its chronology. Our results of $\sim 23.5-23 \mathrm{ka}$ BP from different areas of the site are consistent with the layer's accumulation over a short period. These results accord with recently obtained dates for Kostenki's other KAC sites. Our younger results of 22.5-21 ka BP for different material from Layer III of Kostenki 21 are similarly consistent with a short chronological window for Kostenki's KAC sites. Overall, this and other recent publications support the view that many Kostenki assemblages are chronologically distinct. This provides an important insight into the tempo of Upper Paleolithic cultural change.
\end{abstract}

KEYWORDS: Eastern Europe, Late Pleistocene, radiocarbon dating, Russia.

\section{INTRODUCTION}

\section{The Kostenki Upper Paleolithic}

A sound reconstruction of Upper Paleolithic cultural change requires multilayered sites that show the chronostratigraphic relationships of different assemblages. For this reason, the complex of 26 open-air sites around the villages of Kostenki and Borshchevo (Voronezh region, Russia; Figure 1; henceforth simply "Kostenki") is key for the period in Eastern Europe. For over 20 millennia hunter-gatherer groups left behind occupation debris, which frequently became buried by low-energy accumulation of sediment. As a result, around half of Kostenki's sites are multilayered, and some have deep sequences with multiple archaeological horizons separated by sterile ones. Kostenki thus provides an unusually high-resolution archaeological record spanning a large part of the Late Pleistocene.

Kostenki also benefits from a well-understood geological framework (Figure 2), which allows correlation of the different sites. In reality, stratigraphies are complex and often impacted by post-depositional disturbance, but this framework is nonetheless a firm basis for chronology

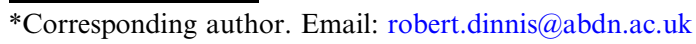




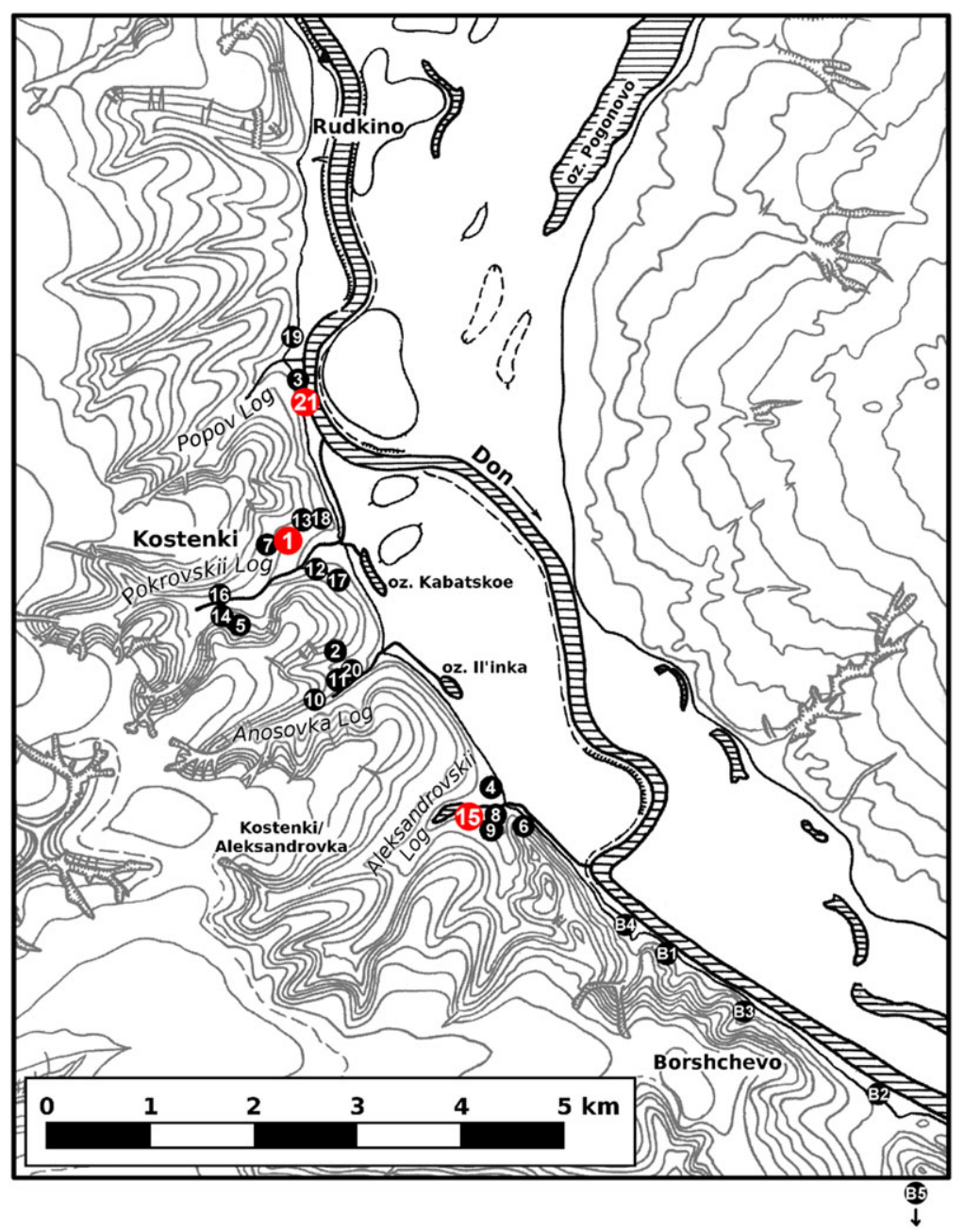

Figure 1 Location of the Kostenki-Borshchevo sites, with Kostenki 21, Kostenki 1 and Kostenki 15 highlighted.

building. The sites also contain abundant material suitable for radiocarbon dating. This includes anthropogenic accumulations of animal bone.

Producing accurate bone dates has proved challenging, due to the well-documented problem of exogenous carbon leading to erroneously young results (Higham 2011). More recent bonedating work using more effective sample pretreatment methods has provided improved radiocarbon chronologies for some Kostenki sites (e.g., Douka and Higham 2017; Dinnis et al. 2018, 2019a), but the precise chronological relationships between others remain unresolved (e.g., Hoffecker et al. 2018; Lisitsyn 2019).

Given its regional importance, a robust, high-resolution chronology for Kostenki has significance well beyond the complex. Here we present and discuss new radiocarbon dates for three key assemblages. 


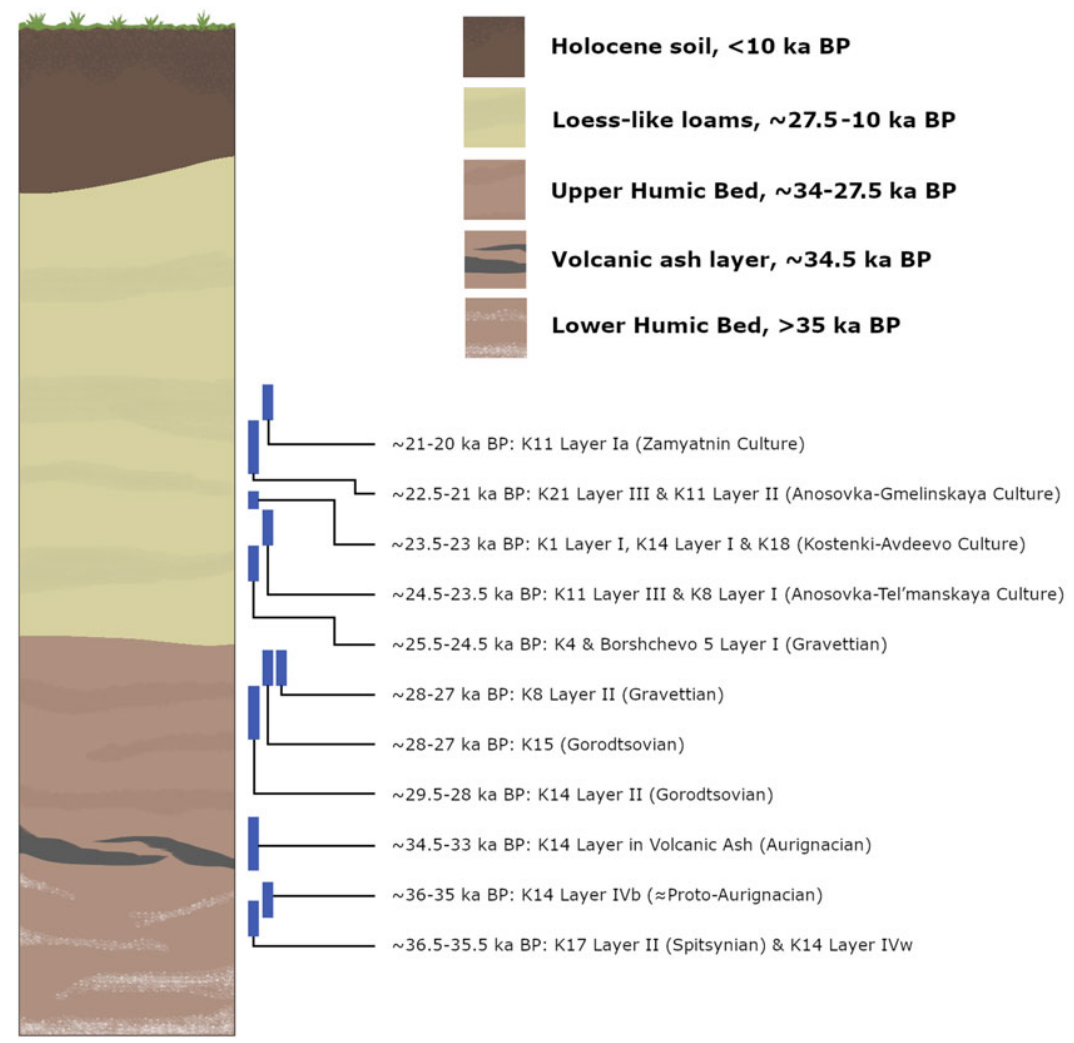

Figure 2 Idealized schematic column of the Kostenki region's geological sequence, showing the major Late Pleistocene/Holocene geological units. The blue bars show the relative chronological positions within this sequence of selected layers from different Kostenki sites: namely recently/well-dated assemblages and others mentioned in this paper. Layers' radiocarbon chronologies are based on Damblon et al. (1996), Sinitsyn et al. (1997), Sinitsyn and Hoffecker (2006), Reynolds et al. (2015, 2017), Douka and Higham (2017), Dinnis et al. (2018, 2019a, this paper) and Pryor et al. (2020). Note each layer's age range represents the period within which each assemblage probably falls, rather than expressing the duration of occupation(s). Note also that most of the loess-like loam deposits appear to date to the earlier part of the given time range.

\section{Kostenki 15 (Gorodtsovskaya)}

The single-layered Kostenki 15 (Figures 1 and 3) was excavated by A.N. Rogachev in 1952. The main concentration of finds was interpreted by Rogachev as the remains of a dwelling, within which was an infant burial. A smaller cluster of finds was located to the north of this ( squares M-H-18-19; Figure 3). As well as the burial and lithic and osseous tool assemblages, Rogachev recovered a large number of horse bones $(n=1501, M N I=11)$, some of which found in anatomical position (Rogachev and Sinitsyn 1982; Sergin 2016).

Kostenki 15 is the eponymous site of the Gorodtsovian (Efimenko 1956; Sinitsyn 1982). Gorodtsovian lithic assemblages are characterized by an abundance of splintered pieces and short, steep-faced end-scrapers, as well as a high incidence of tool types historically viewed as characteristically "Mousterian" (e.g., side-scrapers). Technotypological variation between sites previously classified as Gorodtsovian is, however, markedly high; to an extent the taxon has been used as a catch-all for assemblages not classifiable as Aurignacian (typified 


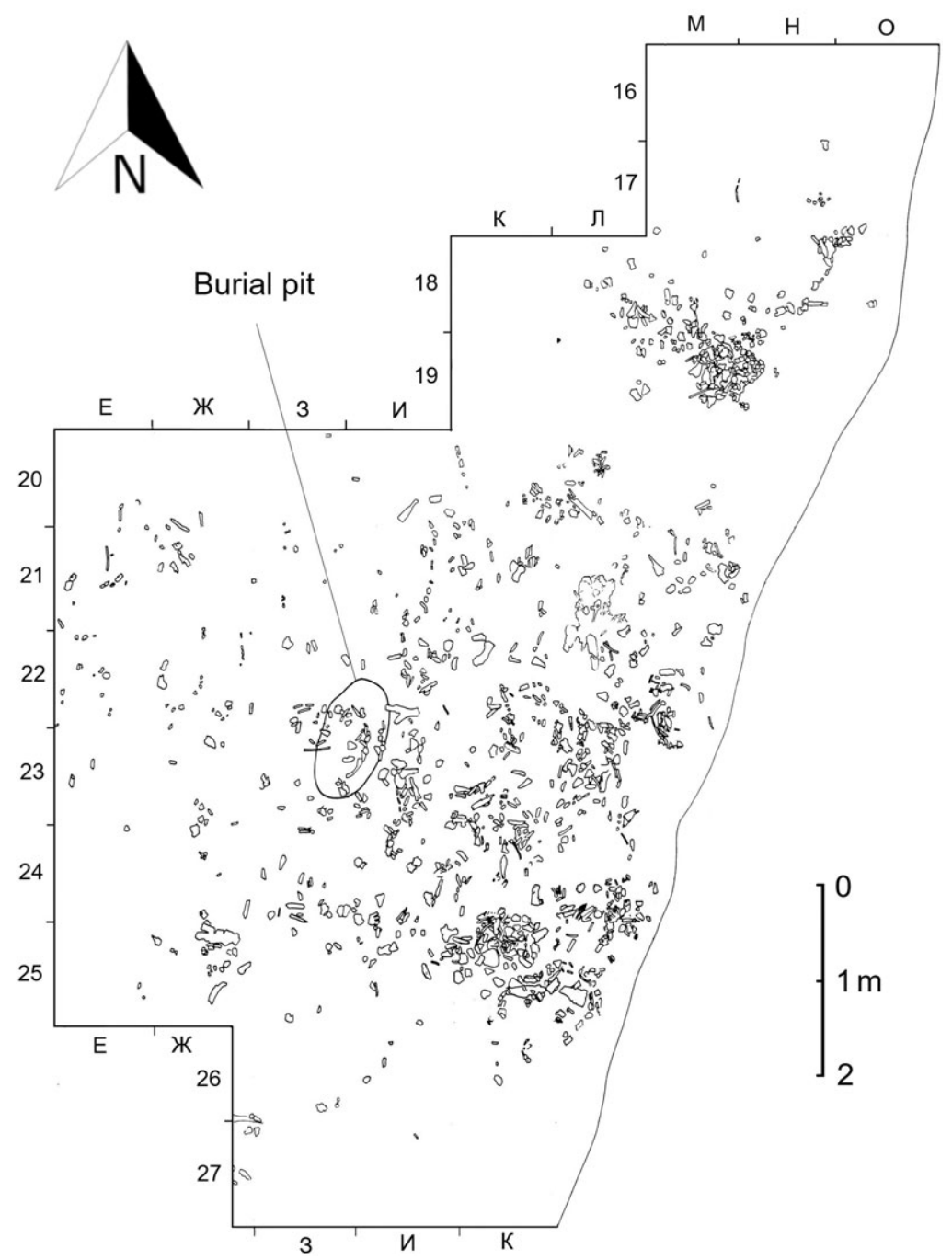

Figure 3 Plan of Kostenki 15 (modified from Sinitsyn 2004), showing the location of the burial pit.

by finely-edge-retouched bladelets) or Gravettian (typified by backed ones) (Sinitsyn 2018). Despite this variation a cultural link between Kostenki 15, Kostenki 14 Layer II, and Kostenki 12 Layer I is demonstrated by the presence of idiosyncratic mammoth-bone "paddles" (Figure 4). Further assemblages from Kostenki 16 and Mira on the Lower Dnieper (Stepanchuk 2013; Hoffecker et al. 2018) are possibly but less certainly related.

The broad chronology of Kostenki's Gorodtsovian assemblages is known from their association with the Upper Humic Bed (see Figure 2). The assemblage whose geochronological position is clearest is Kostenki 14 Layer II, which lies close to the center of the Upper Humic Bed (Velichko et al. 2009; Sedov et al. 2010). A finer resolution chronology is hindered by an inconsistent radiocarbon record (Sinitsyn et al. 1997; Sinitsyn and Hoffecker 2006). Kostenki 15 has been especially poorly dated until now: all three 


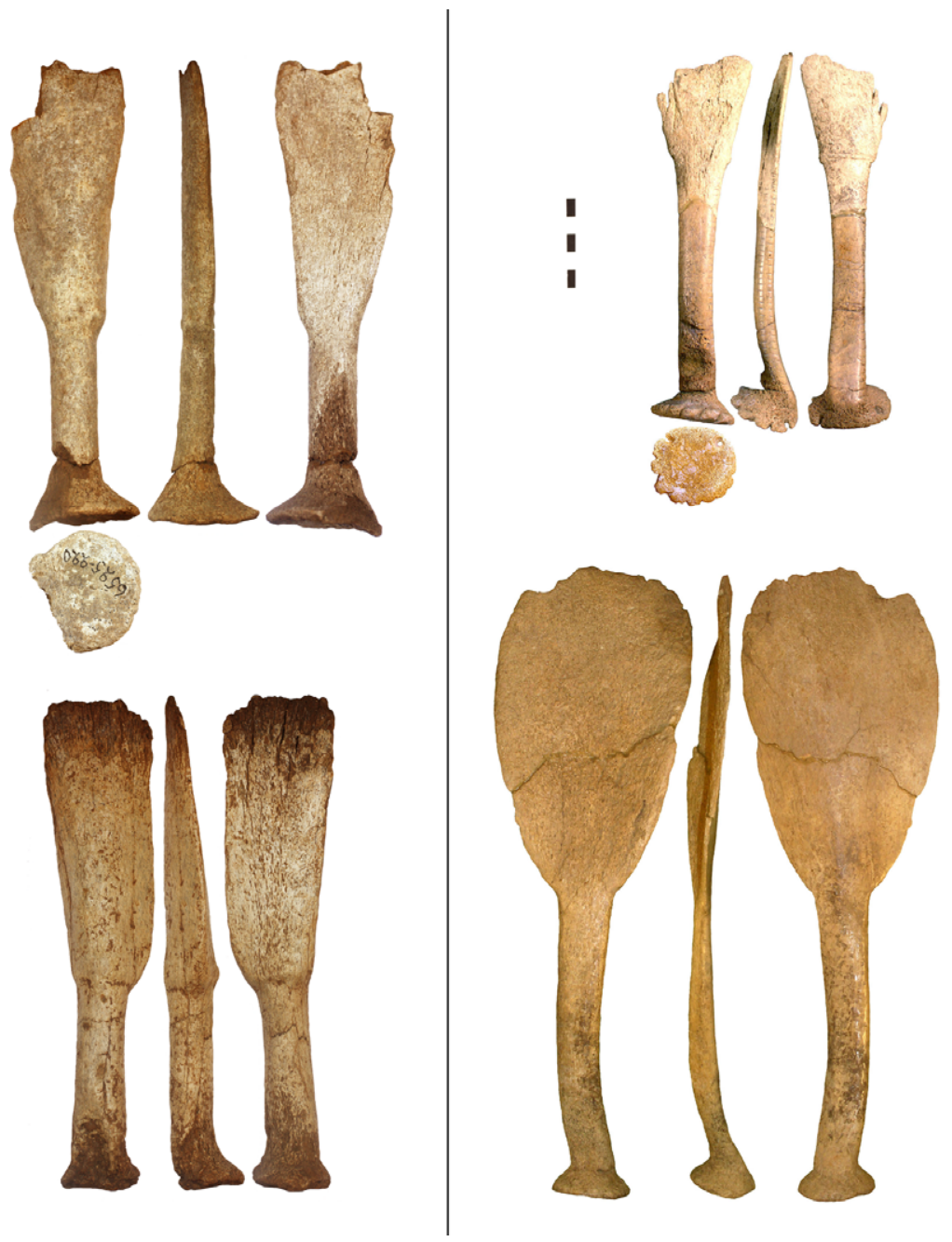

Figure 4 Gorodtsovian bone "paddles" from Kostenki 15 (left) and Kostenki 14 Layer II (right).

previously published radiocarbon dates of $16,895 \pm 200 \mathrm{BP}, 21,720 \pm 570 \mathrm{BP}$ and $25,700 \pm 250$ BP (see Appendix) appear to be underestimates.

To improve Kostenki 15's chronology we produced six new radiocarbon dates (Table 1). Two were from long bone fragments associated with the burial fill, with a third from a long bone fragment whose precise provenance is uncertain, but which came from the site's main cluster of material. The three remaining dates were from bones identifiable with certainty as horse. To ensure we dated different animals we selected three right-side calcanea. Two of these three specimens were found in the larger concentration of finds, with the other from the smaller, northern cluster (Table 1, Figure 3). All samples were processed using the Oxford Radiocarbon Accelerator Unit's (ORAU) routine procedure, as described by Brock et al. (2010). Because glue was visible on the surface of one sample (OxA-26767), we applied an additional acetone, methanol and chloroform solvent wash step (Table 1). One of our 
Table 1 New radiocarbon dates for Kostenki 15, Kostenki 1 Layer I and Kostenki 21 (see also Figure 5). No other dates (or failed dates) were produced for these contexts in the course of this work. P-Code refers to the pretreatment method applied: AF denotes ultrafiltration of bone collagen extract (see Brock et al. 2010), with * denoting an acetone, methanol and chloroform solvent wash. Stable isotope ratios of carbon and nitrogen are presented in \%o relative to VPDB and AIR respectively with a mass spectrometric precision of $\pm 0.2 \%$ and $\pm 0.3 \%$ respectively. Yield represents the weight of ultrafiltered collagen extracted in milligrams. \%Yld is the percent yield of extracted collagen with respect to the starting weight of the bone analyzed. Used is the weight of bone used, also in $\mathrm{mg}$. \% $\mathrm{C}$ is the carbon present in the combusted gelatin and ought to be $\sim 40-43 \%$. $\mathrm{CN}$ atomic ratios ought to range from 2.9 to 3.5 .

\begin{tabular}{|c|c|c|c|c|c|c|c|c|c|c|c|c|c|}
\hline Site/layer & $\begin{array}{l}\text { Excavation/square/feature, finds } \\
\text { number, museum identifier }\end{array}$ & $\begin{array}{l}\text { Sample, species, } \\
\text { element }\end{array}$ & $\begin{array}{l}\text { P- } \\
\text { code }\end{array}$ & $\begin{array}{l}\text { Used } \\
(\mathrm{mg})\end{array}$ & $\begin{array}{l}\text { Yield } \\
(\mathrm{mg})\end{array}$ & $\begin{array}{l}\% \\
\text { Yield }\end{array}$ & $\begin{array}{l}\% \\
\mathrm{C}\end{array}$ & $\delta^{13} \mathrm{C}$ & $\delta^{15} \mathrm{~N}$ & $\mathrm{C} / \mathrm{N}$ & $\begin{array}{c}\text { OxA } \\
\text { number }\end{array}$ & $\begin{array}{l}\text { Conventional } \\
{ }^{14} \mathrm{C} \text { age (BP) }\end{array}$ & Notes \\
\hline Kostenki 15 & Sq. M-19, 971, 25183 (272) & Horse, calcaneum & $\mathrm{AF}^{*}$ & 510 & 46.59 & 9.1 & 46 & -19.4 & $\mathrm{n} / \mathrm{a}$ & 3.4 & 32667 & $27,430 \pm 250$ & $\begin{array}{l}\text { Different animal from } \\
\text { OxA-32668 \& OxA- } \\
32599\end{array}$ \\
\hline Kostenki 15 & Sq. K-25, 541, 25183 (284) & Horse, calcaneum & $\mathrm{AF}^{*}$ & 540 & 40.25 & 7.5 & 43 & -19.3 & $\mathrm{n} / \mathrm{a}$ & 3.4 & 32668 & $27,410 \pm 260$ & $\begin{array}{l}\text { Different animal from } \\
\text { OxA-32667 \& OxA- } \\
32599\end{array}$ \\
\hline Kostenki 15 & Sq. Л-23, 99, 25183 (282) & Horse, calcaneum & $\mathrm{AF}^{*}$ & 740 & 68.05 & 9.2 & 43 & -20 & 7.8 & 3.4 & 32599 & $27,410 \pm 260$ & $\begin{array}{l}\text { Different animal from } \\
\text { OxA-32667 \& OxA- } \\
32668\end{array}$ \\
\hline Kostenki 15 & Burial fill above skeleton & $\begin{array}{l}\text { Large mammal, } \\
\text { long bone } \\
\text { fragment }\end{array}$ & $\mathrm{AF}$ & 940 & 7 & 0.7 & 40 & -21.4 & 8.7 & 3.5 & $X-2484-49$ & $22,630 \pm 160$ & Low collagen yield \\
\hline Kostenki 15 & Sq. ? $-22-23$ & $\begin{array}{l}\text { Large mammal, } \\
\text { long bone } \\
\text { fragment }\end{array}$ & $\mathrm{AF}^{*}$ & 1100 & 33.2 & 3 & 42 & -19.4 & 8.7 & 3.2 & 26767 & $26,860 \pm 240$ & $\begin{array}{l}\text { Some glue on the bone, } \\
\text { avoided during } \\
\text { sampling }\end{array}$ \\
\hline Kostenki 15 & $\begin{array}{l}\text { Sq. 3-И-22-23 (associated } \\
\text { with burial fill) }\end{array}$ & $\begin{array}{l}\text { Large mammal, } \\
\text { long bone } \\
\text { fragment }\end{array}$ & $\mathrm{AF}$ & 1100 & 49.6 & 4.5 & 42 & -19.5 & 6.2 & 3.2 & 27222 & $27,330 \pm 240$ & \\
\hline $\begin{array}{l}\text { Kostenki 1, } \\
\text { Layer I }\end{array}$ & $\begin{array}{l}1982 \text { excavation Sq. T-4/4 } \\
\text { base of pit (Dwelling pit E) }\end{array}$ & $\begin{array}{l}\text { Large mammal, } \\
\text { long bone } \\
\text { fragment }\end{array}$ & $\mathrm{AF}$ & 900 & 35.8 & 4 & 42 & -20.2 & 7.8 & 3.2 & 26764 & $23,530 \pm 170$ & $\begin{array}{l}\text { Worked (polisher) \& cut- } \\
\text { marked }\end{array}$ \\
\hline $\begin{array}{l}\text { Kostenki 1, } \\
\text { Layer I }\end{array}$ & $\begin{array}{l}1982 \text { excavation Sq. Л-16 } \\
\text { (Dwelling pit ЛМ-13-16) }\end{array}$ & Horse, metapodial & $\mathrm{AF}^{*}$ & 700 & 41.13 & 5.9 & 45 & -20.4 & 4 & 3.2 & 26765 & $23,260 \pm 160$ & Worked (awl) \\
\hline $\begin{array}{l}\text { Kostenki 1, } \\
\text { Layer I }\end{array}$ & $\begin{array}{l}1988 \text { excavation Sq. У-75 } \\
\text { (Dwelling pit ТУФХ-72-75) }\end{array}$ & $\begin{array}{l}\text { Fox/Hare, long } \\
\text { bone fragment }\end{array}$ & $\mathrm{AF}$ & 840 & 34.6 & 4.1 & 42 & -19.7 & 3.3 & 3.2 & 26766 & $23,510 \pm 160$ & Cut-marked \\
\hline $\begin{array}{l}\text { Kostenki 21, } \\
\text { Layer I }\end{array}$ & 1971 excavation Sq. Ч-72 & Mammoth, rib & $\mathrm{AF}^{*}$ & 1030 & 74.6 & 7.2 & 45 & -20.1 & 10 & 3.1 & 26758 & $21,250 \pm 130$ & \\
\hline $\begin{array}{l}\text { Kostenki 21, } \\
\text { Layer II }\end{array}$ & 1979 excavation Sq. E'-119 & Mammoth, tibia & AF & 1100 & 75.1 & 6.8 & 58 & -20.4 & 9.2 & 3.2 & 27218 & $20,590 \pm 120$ & \\
\hline $\begin{array}{l}\text { Kostenki } 21, \\
\text { Layer III }\end{array}$ & 1971 excavation Sq. K-32 & $\begin{array}{l}\text { Large mammal, } \\
\text { long bone } \\
\text { fragment }\end{array}$ & $\mathrm{AF}$ & 1200 & 46.8 & 3.9 & 42 & -19.1 & 5.4 & 3.2 & 27217 & $21,570 \pm 130$ & Burned? \\
\hline $\begin{array}{l}\text { Kostenki 21, } \\
\text { Layer III }\end{array}$ & 1971 excavation Sq. K-32 & $\begin{array}{l}\text { Large mammal, } \\
\text { long bone } \\
\text { fragment }\end{array}$ & $\mathrm{AF}^{*}$ & 1000 & 38.2 & 3.8 & 43 & -18.7 & 5.9 & 3.1 & 26759 & $21,100 \pm 130$ & \\
\hline $\begin{array}{l}\text { Kostenki } 21, \\
\text { Layer III }\end{array}$ & 1971 excavation Sq. К-33 & $\begin{array}{l}\text { Large mammal, } \\
\text { long bone } \\
\text { fragment }\end{array}$ & $\mathrm{AF}^{*}$ & 930 & 29.6 & 3.2 & 46 & -19.7 & 6.7 & 3.1 & 26760 & $22,570 \pm 150$ & Retoucher, bearing polish \\
\hline
\end{tabular}




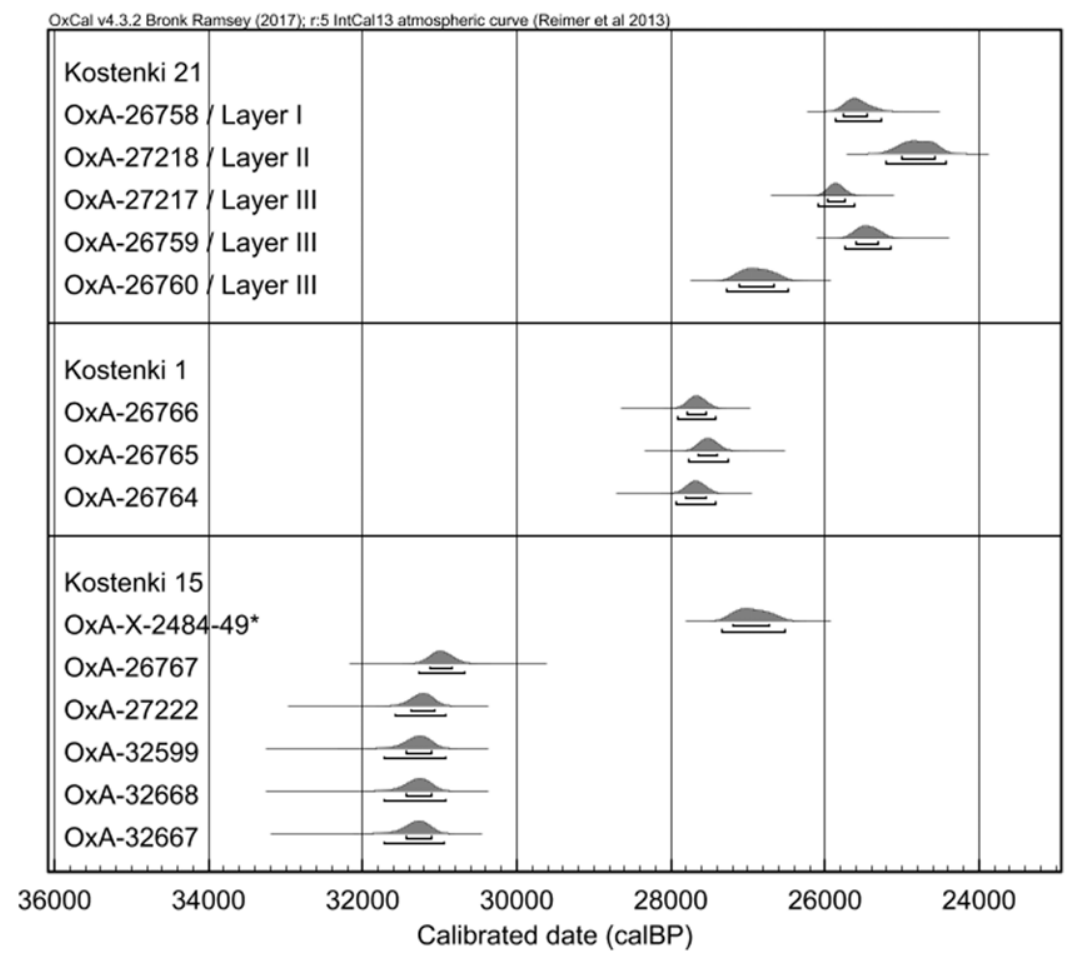

Figure 5 Calibrated ages for the age determinations shown in Table 1 from Kostenki 21, Kostenki 1 Layer I, and Kostenki 15. The asterisk in OxA-X-2484 denotes a radiocarbon determination with a health warning due to low collagen yield $(0.7 \%)$. The dates were calibrated using the IntCal13 curve (Reimer et al. 2013) and the OxCal 4.5 platform (Bronk Ramsey 2017).

primary objectives was to test whether the horse bone accumulation was the result of activity over a brief period. No glue was evident on the three dated horse bones (OxA-32667, OxA32668 and OxA-32599), but to allow a greater confidence in the results we also applied a solvent wash to these samples (Table 1).

Excluding the sample for which the collagen yield was low (OxA-X-2484-49), our five results of 27.5-27 ka BP show a good degree of consistency (Table 1, Figure 5). That said, given the difficulty of producing accurate dates for glued bones even when an additional solvent wash step is applied (e.g., Dinnis et al. 2019a), the youngest of these results (OxA-26767; 26,860 \pm $240 \mathrm{BP}$ ) is best treated as a minimum age. Despite coming from different parts of the site, the remaining four dates, including the three identified horse bones, show a particularly pronounced level of consistency at $\sim 27.4-27.3 \mathrm{ka} \mathrm{BP}$ (Table 1). This is consonant with them belonging to a broadly contemporary deposit.

\section{Kostenki 1 (Polyakovskaya), Layer I}

The uppermost Layer I of Kostenki 1 is among Eastern Europe's most important Upper Paleolithic sites. Extensive excavation of the layer throughout the 20th century, primarily by P.P. Efimenko, Rogachev and then N.D. Praslov, unearthed a large archaeological assemblage $(>55,000$ lithic pieces) and the remains of habitation complexes (Rogachev 


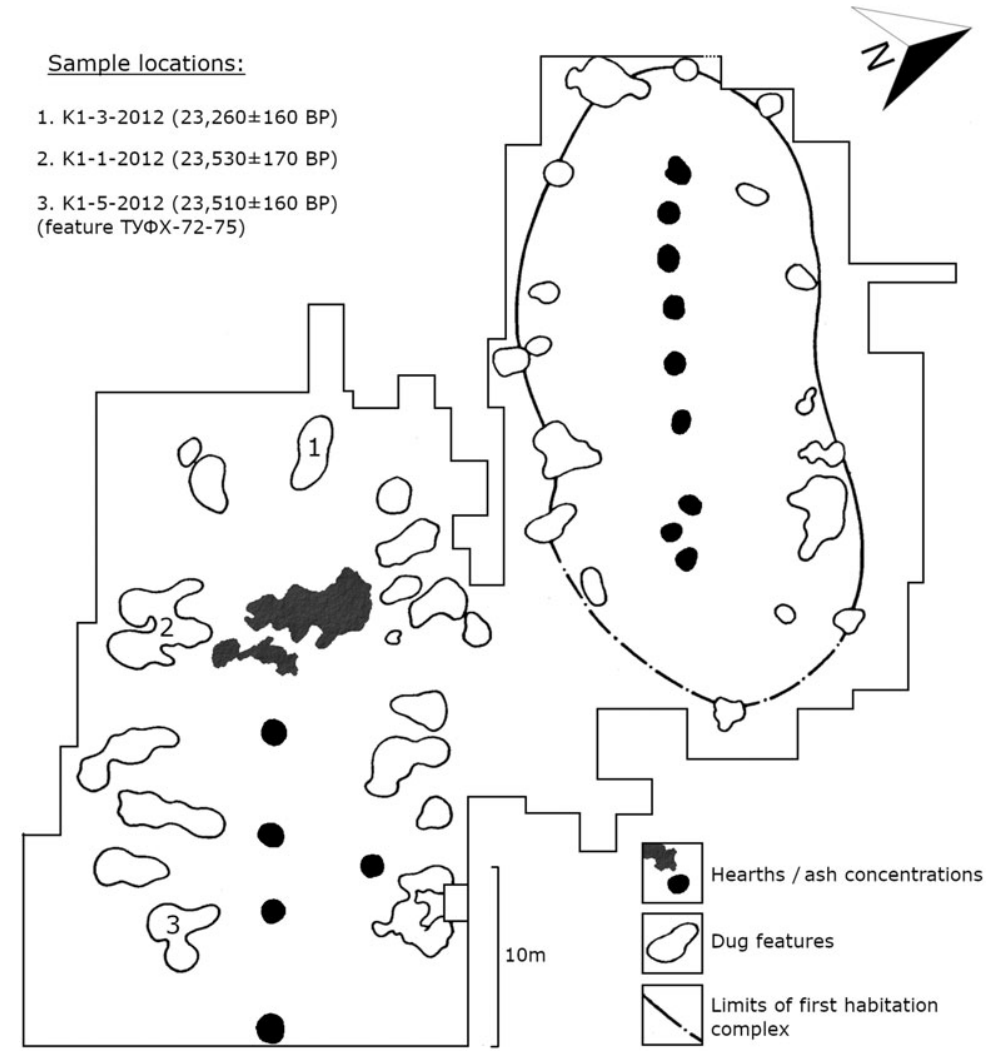

Figure 6 Plan of Kostenki 1 Layer I, showing the first habitation complex (right) and the incompletely excavated second complex (left) (modified from Desbrosse and Kozłowski 2001). The different pits from which our dated samples came are marked.

et al. 1982; Anikovich et al. 2019; Figure 6). An abundance of material has allowed a good characterization of the assemblage. It includes shouldered points, Kostenki knives and female figurines: the defining features of the Kostenki-Avdeevo Culture (KAC). Among other assemblages attributed to the same cultural group are Kostenki 14 Layer I, Kostenki 13, Kostenki 18, Avdeevo and Zaraisk, with Khotylevo 2 and Gagarino also sometimes linked (Sinitsyn 2007; Reynolds et al. 2017; Lisitsyn 2019).

Because some of these sites have large and well-defined assemblages their cultural connection is generally accepted. As a result, the longevity of occupation(s) represented at single sites-and the longevity of the KAC group overall-has been widely discussed (e.g., Amirkhanov et al. 2001; Anikovich et al. 2008; Zaretskaya et al. 2018). Debates largely focus on how to interpret the sites' considerable number of radiocarbon dates. Some favor a "long chronology," viewing a several-thousand-year span of dates as evidence that archaeological layers represent long occupations or several short ones over a long time. Others favor a "short chronology," viewing many of the dates as inaccurate, and seeing multiple phases of activity represented in a layer as likely to be chronologically indistinguishable at the resolution of radiocarbon dating (see Zaretskaya et al. 2018 for an overview of these debates). 
There are 55 previous dates for Kostenki 1 Layer I, which span $\sim 15,000{ }^{14} \mathrm{C}$ yrs (Sinitsyn et al. 1997; Anikovich et al. 2008; Khlopachev 2016; Zheltova and Zaretskaya 2018; Appendix 1). If the younger dates $(<20 \mathrm{ka} \mathrm{BP}$ ) and less precise dates (those with errors $>1,000$ ) are dismissed as probably problematic, the remaining $39(=71 \%)$ are reasonably evenly distributed over the range $\sim 24-20 \mathrm{ka} \mathrm{BP}$. This span of dates, however, is seemingly inconsistent with the layer's well-structured planigraphy and the technotypological coherence of its assemblage, which instead point to its formation over a short period (Rogachev 1969; Sinitsyn et al. 1997).

To examine this issue, we dated bones from the 1980s excavation of the second habitation complex, from which all of the previous radiocarbon dates for Layer I have come. In its composition this complex resembles the more completely excavated first complex: a line of hearths is surrounded by features interpreted as dwelling and storage pits (Figure 6). Our three dated samples came from features in different parts of the second complex (Table 1, Figure 6). Two of the dated bones bear signs of human modification (Table 1). Samples were processed using ORAU's routine procedure. Because one of the sampled bones was a worked bone awl and may have been treated with preservatives, we included an acetone, methanol and chloroform solvent wash for this sample (OxA-26765).

Our results of 23,530 $\pm 170 \mathrm{BP}, 23,260 \pm 160 \mathrm{BP}$ and 23,510 $\pm 160 \mathrm{BP}$ (Table 1; Figure 5) are consistent with a short chronology for the complex, and therefore for the layer.

\section{Kostenki 21 (Gmelinskaya)}

Different material is known from Layer III of Kostenki 21 (Figure 1), which was the subject of extensive excavation in the 1960s and 70s. Whereas the site's two upper archaeological layers yielded very few artefacts, the lowermost Layer III contained $>35,000$ lithic pieces, making it one of Kostenki's major assemblages. The Layer III lithic assemblage is characterized by two point types: shouldered points, which are overall smaller and especially narrower than those in KAC assemblages, and Anosovka points. The latter have also been identified at Layer II of Kostenki 11 (Anosovka II), and a cultural link between Kostenki 21 Layer III and Kostenki 11 Layer II has been widely postulated (Rogachev and Popov 1982; Lisitsyn and Dudin 2019; Reynolds et al. 2019). At Kostenki 21 Layer III, shouldered points and Anosovka points are found in separate areas (southern and northern respectively), which may reflect separate chronologically close but culturally distinct occupations (Lisitsyn 2019; Reynolds et al. 2019).

Unlike Kostenki 15 and Kostenki 1, which lie in deposits equivalent to the River Don's second terrace, Kostenki 21 is located on the Don's first terrace. This has led to its three layers being sealed by substantial alluvial and colluvial deposits: Layer III is separated from the overlying Layer II by $\sim 1 \mathrm{~m}$, with the uppermost Layer I a further $\sim 1.5 \mathrm{~m}$ higher. However, Kostenki 21 's location on the first terrace has also meant difficulties in high-resolution geochronological correlation with other Kostenki sites. Generally, Layer III is understood as close in age to several other layers, including Kostenki 1 Layer I and other KAC assemblages. While some have viewed Kostenki 21 Layer III as probably slightly younger than these KAC sites (Bessudnov 2019; Lisitsyn 2019; Reynolds et al. 2019), their different ages cannot be confidently concluded from existing radiocarbon dates (see Appendix).

To help clarify its age we produced three new dates for Layer III of Kostenki 21. All dated samples came from the 1971 excavation of Northern Complex III (see Reynolds et al. 2019: fig. 3): an oval concentration of archaeological remains, $\sim 4 \mathrm{~m}$ in diameter, with a hearth at its center, where Anosovka points were found. The complex's structured planigraphy and 
lithic refits led Praslov and Ivanova (1982; Ivanova 1985) to view it as the remains of a dwelling structure. We also produced single dates for the overlying Layers II and I, primarily to constrain Layer III's age. Samples were processed using ORAU's routine procedure, including a cautionary acetone, methanol and chloroform solvent wash for the samples that were suspected to have been contaminated by conservation materials (Table 1).

Our new dates for Layer III of 21,570 $\pm 130 \mathrm{BP}, 21,100 \pm 130 \mathrm{BP}$ and 22,570 $\pm 150 \mathrm{BP}$ (Table 1; Figure 5) are compatible with the site's geochronological position. However, they do not overlap statistically as a group $\left(T^{\prime}=6.54\right.$; chi-squared $=3.84$ with 2 degrees of freedom). It is unclear how this should be interpreted. The presence in the layer of spatially distinct assemblages means it may contain material of (observably) different ages, although the excavator's interpretation of Northern Complex III would suggest all of the dated samples should be cotemporary. Alternatively, it is possible that the younger dates are underestimates of the samples' ages. Irrespective of this, we can note that our results agree well with the four older of the five previous dates for the layer (see Appendix). Importantly, all of these dates are younger than our results for the KAC Kostenki 1 Layer I.

\section{DISCUSSION}

Recent bone-dating work has clarified the chronology of several Kostenki layers (Reynolds et al. 2015, 2017; Douka and Higham 2017; Dinnis et al. 2018, 2019a). New dates have generally been consistent within each assemblage and have aligned well with Kostenki's geochronology. This work has shown more clearly a chronological separation of assemblages whose chronological relationships were previously unknown or unclear. The net result is a higher resolution reconstruction of Late Pleistocene occupation and a better picture of the tempo of Upper Paleolithic cultural change (Figure 2). This will facilitate more robust synchronic and diachronic inter-assemblage comparisons, and a better understanding of if, and how, assemblages are related.

The results presented here help to do just that, most notably for the Gorodtsovian Kostenki 15. Recently, Hoffecker et al. (2018) have proposed a functional relationship between some of Kostenki's early non-Aurignacian assemblages, especially those classed as Gorodtsovian, and its Aurignacian ones. For Hoffecker et al., differences between them may relate to butchery events and the large horse-bone accumulations at some sites, including Kostenki 15. While site function may account for some features of the Kostenki Upper Paleolithic it cannot easily explain the relationship between its Aurignacian and Gorodtsovian assemblages. Such an explanation requires their contemporaneity, but Aurignacian material appears older.

Kostenki's best-stratified and well-dated Aurignacian assemblage comes from Kostenki 14's Layer in Volcanic Ash. It is currently dated to 34.5-33 ka BP (Dinnis et al. 2019a) (Figure 2). Another typically Aurignacian assemblage from Layer III of Kostenki 1 is likely to be (at least broadly) contemporary (Dinnis et al. 2019a, 2019b). Slightly older layers at Kostenki 14 and Kostenki 17 (Figure 2) share some attributes with ProtoAurignacian assemblages (Dinnis et al. 2019a, 2019b, 2020). Overall, current evidence indicates an age of $\geq 33 \mathrm{ka}$ BP for Kostenki's Aurignacian material.

Gorodtsovian assemblages post-date this. Only at Kostenki 14 are both found in a single stratigraphy, with the younger Gorodtsovian Layer II higher in the sequence. Gorodtsovian assemblages from Kostenki 14 Layer II, Kostenki 15 and Kostenki 12 Layer I were all found within or towards the top of the Upper Humic Bed (Rogachev and Anikovich 1982; 
Rogachev and Sinitsyn 1982; Velichko et al. 2009; Sedov et al. 2010), in contrast to the Kostenki 14 Aurignacian, which was found underlying it. Of all published radiocarbon dates for Gorodtsovian assemblages, the oldest are eight of 13 dates for Kostenki 14 Layer II, which range 29.5-28 ka BP (Sinitsyn and Hoffecker 2006; Sinitsyn 2014; Douka and Higham 2017). This is significantly younger than the Aurignacian material at the same site. Our new results of $\sim 27.5-27 \mathrm{ka}$ BP for the Gorodtsovian Kostenki 15 are similarly much younger. Kostenki's Aurignacian and Gorodtsovian can therefore be separated on chronological, rather than simply functional, grounds (Figure 2).

More broadly, the range of $33.5-25.5$ ka BP proposed by Hoffecker et al. (2018: 54) for a functional variant of the Aurignacian supposes a long and late Aurignacian chronology that is highly unlikely. The latest Aurignacian layers in Western Europe and in the Upper and Middle Danube regions seem to predate 29 ka BP (Jöris et al. 2010; Higham et al. 2011; Dinnis et al. 2019b), and there is good chronostratigraphic agreement of Aurignacian-type bladelet tools between Eastern and Western Europe (Dinnis et al. 2019b). Furthermore, comparable (postAurignacian) Gravettian material in Western, Central and Eastern Europe is apparently evident by 28.5 ka BP (Jöris et al. 2010; Reynolds and Green 2019; Douka et al. 2020). The picture that emerges is of broad chronocultural agreement between Kostenki and the richer and better dated Aurignacian record further west. As for the rest of Europe, the very latest age for Eastern European Aurignacian material may be assumed to be $\sim 29 \mathrm{ka}$ BP.

Our results also help clarify the chronological relationships of some of Kostenki's younger assemblages. The new radiocarbon dates of 23.5-23 ka BP for Kostenki 1 Layer I (Table 1) are consistent with a short chronology for the layer. They support the view of the excavators and others that the layer's well-defined habitation structures and coherent artefact assemblage represent activity over a few years or (at most) generations, rather than activity spanning several millennia (Rogachev 1969; Sinitsyn et al. 1997; Praslov 2003).

Such a conclusion is, though, counter to that of Zheltova and Zaretskaya (2018), who recently presented new dates on burnt bone for the layer ranging in age from 20,850 $\pm 160 \mathrm{BP}$ (GIN4892 ) to $22,175 \pm 260 \mathrm{BP}$ (GIN-4895) (Appendix 1). For them, the span of the layer's dates is evidence for a long history of occupation and for the site having a complex, palimpsest nature. It is noteworthy that one of Zheltova and Zaretskaya's (2018) samples (GIN-4901) came from the same feature as one of ours (OxA-26766): a dugout dwelling pit, up to $1 \mathrm{~m}$ deep, found across squares ТУ $\Phi Х-72-75$ (Figure 6). In total there are six radiocarbon dates from this feature, ranging from 21,880 $\pm 200 \mathrm{BP}$ (GIN-4901) to 23,770 $\pm 200 \mathrm{BP}$ (LE-2951) (Table 2). Like similar features in the layer, aspects of its layout and fill are perhaps evidence for multiple episodes of activity (Praslov et al. 1978; Praslov 1987; AS pers. obs.), but there is no reason to think this activity would span a period observable at the resolution of radiocarbon dating. In light of this, we suggest that the discrepancy between Zheltova and Zaretskaya's (2018) dates and our own is more likely to relate to the material being dated. Burnt bone is typically low in carbon and often remaining pyrolyzed collagen cannot be separated effectively from low carbon sediments in the bone matrix. If the sediment carbon is of a different age than the residual collagen itself, erroneous ages will result. Analytical assessments of the integrity of extracted collagen are not possible when it is pyrolyzed and generally we observe that dates derived from burnt bones are usually underestimates of the true age of the sample, often substantially. We note here that of the six dates for the pit across squares ТУФХ-72-75, the two $<23 \mathrm{ka}$ BP are both from burnt bone (Table 2). They therefore ought to be considered likely to be problematic. 
Table 2 Radiocarbon dates for material from the dugout feature ТУ $\Phi Х-72-75$ of Kostenki 1 Layer I (see Figure 6).

\begin{tabular}{|c|c|c|c|c|}
\hline Square/context & Sample & Lab code & $\begin{array}{c}\text { Conventional } \\
\text { age (BP) }\end{array}$ & Reference \\
\hline 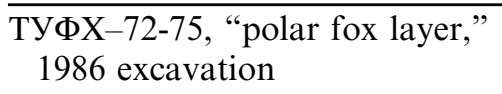 & Burned bone & GIN-4901 & $21,880 \pm 200$ & Zheltova and Zaretskaya 2018 \\
\hline ТУФХ-72-75 & Burned bone & GIN-4903 & $22,200 \pm 500$ & Sinitsyn et al. 1997 \\
\hline ТУФХ-72-75 & Mammoth tooth & LE-3289 & $23,260 \pm 680$ & Sinitsyn et al. 1997 \\
\hline ТУФХ-72-75 & Burned bone & LE-3286 & $23,490 \pm 420$ & Sinitsyn et al. 1997 \\
\hline $\begin{array}{l}\text { ТУФХ-72-75, sq. У-75, } \\
1988 \text { excavation }\end{array}$ & Bone (cutmarked) & OxA-26766 & $23,510 \pm 160$ & This paper \\
\hline ТУФХ-72-75 & Mammoth tooth & LE -2951 & $23,770 \pm 200$ & Sinitsyn et al. 1997 \\
\hline
\end{tabular}


Given the excavators' observations, problems evident in the existing corpus of radiocarbon dates, and the consistency of our new dates of $\sim 23.5-23 \mathrm{ka} \mathrm{BP}$, a short chronology for Kostenki 1 Layer I is the most appropriate reading of the evidence. This is also consistent with recently produced dates of $\sim 23.5-23 \mathrm{ka}$ BP for Kostenki's other KAC sites (Douka and Higham 2017; Reynolds et al. 2017). This includes Kostenki 18, for which the most recent age estimate of $\sim 23.5 \mathrm{ka} \mathrm{BP}$ (Reynolds et al. 2017) for the site's child burial has been questioned (Kuzmin 2019). Kuzmin (2019) has argued that dates of $<21 \mathrm{ka}$ BP for mammoth bones associated with the burial suggest our new date for the burial itself is erroneously old. Kuzmin's (2019) argument assumes that previous dates from bone untreated with conservation materials can be considered accurate, an assumption now welldemonstrated not to be true for bone from Kostenki (Dinnis et al. 2019a). Unlike the site's previous dates, Reynolds et al.'s (2017) new radiocarbon age was produced using HYP pretreatment, which permits dating of a specific molecule, hydroxyproline, rather than collagen, which may still contain contaminant carbon (Devièse et al. 2018). As well as HYP pretreatment having a sound methodological basis (Devièse et al. 2018; Higham 2019), studies have shown that for Upper Palaeolithic-age bones it produces demonstrably accurate results where other pretreatment methods produce those that are erroneously young (e.g., Bourrillon et al. 2018; Dinnis et al. 2019a). For these reasons, Reynolds et al.'s (2017) age of $\sim 23.5 \mathrm{ka}$ BP should be considered the most reliable result for the site, and therefore the only accurate one. When Kostenki 18's previous dates are treated as unreliable, there is no reason to conclude that an age of $\sim 23.5 \mathrm{ka} \mathrm{BP}$ "is not in accordance with the stratigraphy of the site" (Kuzmin 2019: 1067); nothing in Kostenki 18's stratigraphy is inconsistent with Reynolds et al.'s (2017) proposed age (Rogachev 1953, 1959).

Altogether, recent work therefore points to a short, shared chronology of $\sim 23.5-23 \mathrm{ka}$ BP for all of Kostenki's KAC sites (Douka and Higham 2017; Reynolds et al. 2017; this paper). This chronology is also consistent with our results for Layer III of Kostenki 21. Our dates of $~ 22.5-$ $21 \mathrm{ka}$ BP (Table 1, Figures 2 and 5) support a younger age than that of KAC layers. These results provide additional evidence that Kostenki 21 Layer III is contemporary with Kostenki's other Anosovka point assemblage-Kostenki 11 Layer II-for which the older of two dates is 21,800 \pm 200 BP (GIN-2531) (Rogachev and Popov 1982). An age of 22.5-21 ka BP for these Anosovka point assemblages by extension implies a short chronological window for older KAC ones.

\section{CONCLUSION}

Kostenki's archaeological value lies not just in its multiple and often large Upper Paleolithic assemblages, but also in the quality of the chronological data the sites provide. There is abundant dateable material connected to human activity, and the area has a wellresearched geochronological framework that allows a degree of corroboration for individual radiocarbon dates. This is particularly important for the earlier part of the Upper Paleolithic, where producing consistently accurate radiocarbon dates has proved difficult. Thanks to the application of rigorous decontamination protocols, the bone dates presented here provide an improved chronology for key Kostenki sites whose precise chronology was previously unestablished or unclear.

Our new results clarify the relationships between some Kostenki sites. New dates from the Gorodtsovian Kostenki 15 are consistent with its archaeological layer deriving from a short period of activity. Importantly, these dates also clarify that it is unrelated to Aurignacian 
assemblages. Our results from the KAC Layer I of Kostenki 1 are similarly consistent with its accumulation over a short period. This is in line with its well-structured planigraphy and the technotypological coherence of its artefact assemblage and suggests that many of the layer's previous radiocarbon dates are underestimates of the samples' real ages. Importantly, our new dates for Kostenki 1 Layer I agree with recent results of $23.5-23 \mathrm{ka}$ BP for other KAC sites at Kostenki, suggesting they together represent a relatively short-lived and culturally distinct period of occupation in the area. Further support for this interpretation comes from our slightly younger dates for culturally different material from Layer III of Kostenki 21.

Along with other recently produced dates, all of our results contribute to a refined picture of intermittent occupation over $\sim 20,000{ }^{14} \mathrm{C}$ yrs. When considered overall, this work supports the view that much of the technotypological difference between assemblages reflects chronologically distinct periods of occupation, providing an important insight into the tempo of Upper Paleolithic cultural change.

\section{ACKNOWLEDGMENTS}

This work was funded by the Leverhulme Trust (AHOB3 and RPG-2012-800). We thank the staff of the ORAU past and present for their careful laboratory work. We also thank the reviewers and Editor-in-Chief for their comments. AB and AS acknowledge Russian Science Foundation grant numbers 20-78-10151 and 18-78-00136, and Russian Foundation of Basic Research grant numbers 18-39-20009, 18-00-00837 and 20-09-00233. We also acknowledge the participation of IHMC RAS (state assignment 0184-2019-0001) and ZIN RAS (state assignment AAAA-A19-119032590102-7). We thank the UK Natural Environment Research Council (NERC) for supporting the Oxford node of the National Environmental Isotope Facility (NEIF).

\section{REFERENCES}

Amirkhanov KA, Lev SI, Seleznëv AB. 2001. Problema "paleoliticheskoi derevni" kostënkovskoi kul'tury v svete issledovanii Zaraiskoi stoianki. Kratkie soobshcheniia instituta arkheologii 211: 5-16. In Russian.

Anikovich MV, Popov VV, Platonova, NI. 2008. Ranniaia pora verkhnego paleolita po materialam Kostënkovsko-Borshchëvskogo raiona. In: Anikovich MV, Popov VV, Platonova NI, editors. Paleolit Kostënkovsko-Borshchëvskogo raiona v kontekste verkhnego paleolita Evropy. Saint-Petersburg: Nestor-Istoriia. p. 74-142. In Russian.

Anikovich MV, Lisitsyn SN, Platonova NI, Popov VV, Dudin AE, Fedyunin IV. 2019. Chelovek i mamont v paleolite Evropy. Chast' II. Dnepro-Donskaya istorikokul'turnaya oblast'. Trudy KostenkovskoBorshchevskoi arkheologicheskoi ekspeditsii IIMK RAN. Vol. 8/II. Saint Petersburg: ARS-LONGA. In Russian.

Bessudnov AA. 2019. Le site du Gravettien récent, Kostenki 21 (Gmélinskaia): les résultats préliminaires des travaux archéologiques de sauvetage des années 2013-2016. L'Anthropologie 123(2):423-437.
Brock F, Higham TFG, Ditchfield P, Bronk Ramsey C. 2010. Current pretreatment methods for AMS radiocarbon dating at the Oxford Radiocarbon Accelerator Unit (ORAU). Radiocarbon 52: 103-112.

Bourrillon R, White R, Tartar E, Chiotti L, Mensan R, Clark A, Castel J-C, Cretin C, Higham T, Morala A, Ranlett S, Sisk M, Deviese T, Comeskey DJ. 2018. A new Aurignacian engraving from Abri Blanchard, France: Implications for understanding Aurignacian graphic expression in Western and Central Europe. Quaternary International 491:46-64.

Bronk Ramsey C. 2017. Methods for summarizing radiocarbon datasets. Radiocarbon 59(6):1809-1833.

Damblon F, Haesaerts P, van der Plicht J. 1996. New datings and considerations on the chronology of Upper Palaeolithic sites in the Great Eurasiatic plain. Préhistoire Européenne 9:177-231.

Desbrosse R, Kozłowski, J. 2001. Les Habitats Préhistoriques. Paris: Éditions du C.T.H.S.

Devièse $\mathrm{T}$, Comeskey $\mathrm{D}$, McCullagh $\mathrm{J}$, Bronk Ramsey C, Higham T. 2018. New protocol for compound-specific radiocarbon analysis of archaeological bones. Rapid Communications in Mass Spectrometry 32:373-379. 
Dinnis R, Bessudnov AA, Reynolds N, Douka K, Dudin AE, Khlopachev GA, Sablin MV, Sinitsyn AA, Higham TFG. 2018. The age of the "Anosovka-Tel'manskaya Culture" and the issue of a late Streletskian at Kostenki 11. Proceedings of the Prehistoric Society 84:21-40.

Dinnis R, Bessudnov A, Reynolds N, Devièse T, Pate A, Sablin M, Sinitsyn A, Higham T. 2019a. New data for the Early Upper Paleolithic of Kostenki (Russia). Journal of Human Evolution 127:21-40.

Dinnis R, Bessudnov A, Chiotti L, Flas D, Michel A. 2019b. Thoughts on the structure of the European Aurignacian, with particular focus on Hohle Fels IV. Proceedings of the Prehistoric Society 85:29-60.

Dinnis R, Bessudnov A, Reynolds N, Pate A, Sablin M, Sinitsyn A. 2020. Response to Bataille et al.'s "Technological differences between Kostenki 17/ II (Spitsynskaya industry, Central Russia) and the Protoaurignacian: Reply to Dinnis et al. (2019)" [J. Hum. Evol. (2019), 102685]. Journal of Human Evolution 146:102792.

Douka K, Higham T. 2017. The chronological factor in understanding the Middle and Upper Paleolithic of Eurasia. Current Anthropology 58:480-491.

Douka K, Chiotti L, Nespoulet R, Higham T. 2020. A refined chronology for the Gravettian sequence of Abri Pataud. Journal of Human Evolution 141:102730.

Efimenko PP. 1956. K voprosu o kharaktere istoricheskogo protsessa $\mathrm{V}$ pozdnem paleolite Vostochnoi Evropy (o pyamyatnikakh tak nazyvaemogo seletskogo i grimal'diiskogo tipa). Sovetskaya Arkheologiia XXVI:28-53. In Russian.

Higham TFG. 2011. European Middle and Upper Palaeolithic radiocarbon dates are often older than they look: problems with previous dates and some remedies. Antiquity 85:235-49.

Higham TFG. 2019. Removing contaminants: a restatement of the value of isolating single compounds for AMS dating. Antiquity 93: 1072-1075.

Hoffecker JF, Holliday VT, Stepanchuk VN, Lisitsyn SN. 2018. The hunting of horse and the problem of the Aurignacian on the central plain of Eastern Europe. Quaternary International 492:53-63.

Ivanova MA. 1985. Struktura Gmelinskogo paleoliticheskogo poselniia (po rezul'tatam planigraficheskogo i tipologicheskogo analiza kremnëvogo inventaria). Dissertation avtoreferat, LOIA RAN, Leningrad. In Russian.

Jöris O, Neugebauer-Maresch C, Weninger B, Street M. 2010. The radiocarbon chronology of the Aurignacian to Mid-Upper Palaeolithic transition along the Upper and Middle Danube. In: Neugebauer-Maresch C, Owen LR, editors. New Aspects of the Central and Eastern European Upper Palaeolithic - Methods, Chronology, Technology and Subsistence. Vienna: Mitteilungen der Prähistorischen Kommission 72. p. 101-137.
Khlopachev GA, editor. 2016. Verkhnii paleolit: obrazy, simvoly, znaki. Katalog predmetov iskusstva malykh form i unikal'nykh nakhodok verkhnego paleolita iz arkheologicheskogo sobraniya MAE RAN. Saint. Petersburg: Ekstraprint. In Russian.

Kuzmin YV. 2019. The older, the better? On the radiocarbon dating of Upper Palaeolithic burials in Northern Eurasia and beyond. Antiquity 93:1061-1071.

Lisitsyn SN. 2019. The Eastern Frontier of the Gravettian in the Kostenki-Borshchevo Palaeolithic Locality, the Don Basin, Russia. Vestnik of Saint Petersburg University. History 64(2):525-554.

Lisitsyn SN, Dudin AE. 2019. The Gravettian/ Epigravettian in the Kostenki-Borshevo locality on the Don-the division criteria, cultural interpretation and periodisation. Camera praehistorica 1(2):70-106. In Russian.

Praslov ND. 1987. Kostenki 1: novye fakty i nablyudeniya. In: Shilov VP, editor. Problemy sovetskoy arkheologii $\mathrm{v}$ svete reshenii XXVII s'yezda KPSS. Tezisy delegatov Vsesoyuznoi konferentsii (Suzdal', 1987). Moscow: Nauka. p. 206-207. In Russian.

Praslov ND. 2003. Zemlyanka kak tip zhilogo sooruzheniya v verkhnem paleolite. Pushkarevskii sbornik 2:37-61. In Russian.

Praslov ND, Rogachev AN, Ivanova MA, Popov VV. 1978. Otchet o polevykh rabotakh Kostenkovskoi paleoliticheskoi ekspeditsii v 1978 g. Unpublished report, Institute for the History of Material Culture RAS Archives, Saint Petersburg, F.35. Op.1. 1978. D. 59. In Russian.

Praslov ND, Ivanova MA. 1982. Kostenki 21 (Gmelinskaia stoianka). In: Praslov ND, Rogachev AN, editiors. Paleolit KostenkovskoBorshchevskogo raiona na Donu. 1879-1979: Nekotorye itogi polevykh issledovanii. Leningrad: Nauka. p. 198-210. In Russian.

Pryor AJE, Beresford-Jones DG, Dudin AE, Ikonnikova EM, Hoffecker JF, Gamble C. 2020. The chronology and function of a new circular mammoth-bone structure at Kostenki 11. Antiquity 94(374):323-341.

Reimer PJ, Bard E, Bayliss A, Beck JW, Blackwell PG, Bronk Ramsey C, Buck CE, Cheng H, Edwards RL, Friedrich M, Grootes PM, Guilderson TP, Haflidason H, Hajdas I, Hatté C, Heaton TJ, Hoffmann DL, Hogg AG, Hughen KA, Kaiser KF, Kromer B, Manning SW, Niu M, Reimer RW, Richards DA, Scott EM, Southon JR, Staff RA, Turney CSM, van der Plicht J. 2013. IntCall3 and Marine13 radiocarbon age calibration curves 0-50,000 years cal BP. Radiocarbon 55: 1869-1887.

Reynolds N, Green C. 2019. Spatiotemporal modelling of radiocarbon dates using linear regression does not indicate a vector of demic dispersal associated with the earliest Gravettian 
assemblages in Europe. Journal of Archaeological Science: Reports 27:101958.

Reynolds N, Lisitsyn SN, Sablin MV, Barton N, Higham T. 2015. Chronology of the European Russian Gravettian: new radiocarbon dating results and interpretation. Quartär 62:121-132.

Reynolds N, Dinnis R, Bessudnov AA, Devièse T, Higham T. 2017. The Kostënki 18 child burial and the cultural and funerary landscape of Mid Upper Palaeolithic European Russia. Antiquity 91:1435-1450.

Reynolds N, Germonpré M, Bessudnov AA, Sablin MV. 2019. The Late Gravettian site of Kostënki 21 Layer III, Russia: a chronocultural reassessment based on a new interpretation of the significance of intra-site spatial patterning. Journal of Paleolithic Archaeology 2:160-210.

Rogachev AN. 1953. Otchet o rabote razvedochnogo otriada Paleoliticheskoi ekspeditsii v Kostenkakh v 1953 godu. Unpublished report, IA RAN Archives, Moscow, F.1 R.1, no. 850. In Russian.

Rogachev AN. 1959. Otchet ob issledovanii paleolita v Kostenkakh v 1959 godu. Unpublished report, IA RAN Archives, Moscow, F.1 R.1, no. 1960. In Russian.

Rogachev AN. 1969. Znachenie i rol' sotsial'noi sredy $\mathrm{v}$ razvitii kul'tury pervobytnogo obshchestva. In: Gerasimov, LP, editor. Priroda i razvitiye pervobytnogo obshchestva na territorii Evropeiskoi chasti SSSR. Moscow: Nauka. In Russian.

Rogachev AN, Anikovich MV. 1982. Kostenki 12 (Volkovskaya stoyanka). In: Praslov ND, Rogachev AN, editors. Paleolit KostenkovskoBorshchevskogo raiona na Donu, 1879-1979: Nekotoryye itogi polevykh issledovanii. Leningrad: Nauka. p. 132-140. In Russian.

Rogachev AN, Popov VV. 1982. Kostenki 11 (Anosovka 2). In: Praslov ND, Rogachev AN, editors. Paleolit Kostenkovsko-Borshchevskogo raiona na Donu. 1879-1979: nekotorye itogi polevykh issledovanii. Leningrad: Nauka. p. 116-132. In Russian.

Rogachev AN, Sinitsyn AA. 1982. Kostenki 15 (Gorodtsovskaya stoyanka). In: Praslov ND, Rogachev AN, editors. Paleolit KostënkovskoBorshchëvskogo raiona na Donu. 1879-1979: nekotorye itogi polevykh issledovanii. Leningrad: Nauka. p. 162-171. In Russian.

Rogachev AN, Praslov ND, Anikovich MV, Beliaeva VI, Dmitrieva TN. 1982. Kostënki 1 (stoianka Poliakova). In: Praslov ND, Rogachev AN, editors. Paleolit Kostënkovsko-Borshchëvskogo raiona na Donu. 1879-1979: nekotorye itogi polevykh issledovanii. Leningrad: Nauka. p. 42-66. In Russian.

Sedov SN, Khokhlova OS, Sinitsyn AN, Korkka, MA, Rusakov AV, Ortega B, Solleiro E, Rozanova MS, Kuznetsova AM, Kazdym AA. 2010. Late Pleistocene Paleosol Sequences as an instrument for the local paleographic reconstruction of the Kostenki 14 key section (Voronezh Oblast) as an example. Eurasian Soil Science 43(8):876-892.
Sergin VY. 2016. Concentration of cultural remains and a burial at Kostenki 15. Rossiyskii arkheologicheskii ezhegodnik 5-6:36-52. In Russian.

Sinitsyn AA. 1982. Gorodtsovskaya pozdnepaleoliticheskaya kul'tura $\mathrm{i}$ ee mesto $\mathrm{v}$ paleolite Russkoi ravniny. Dissertation aftoreferat, LOIA AS, Leningrad. In Russian.

Sinitsyn, AA. 2004. Les sépultures de Kostenki: chronologie, attribution culturelle, rite funéraire. In: Otte M, editor. La Spiritualité: Actes du colloque de la commission 8 de l'UISPP (Paléolithique supérieur), Liège, 10-12 décembre 2003. Liège: ERAUL 106, p. 237-244.

Sinitsyn A. 2007. Variabilité du Gravettien de Kostienki (Bassin moyen du Don) et des territoires associés. Paléo 19:181-202.

Sinitsyn AA. 2014. Preryvistost' i preyemstvennost' v paleolite Kostenok. In: Bessudnov AN, editor. Verkhnedonskoi arkheologicheskii sbornik. Lipetsk: LGPU. p. 66-76. In Russian.

Sinitsyn A. 2018. The Gorodtsovian as a particular cultural phenomenon of the Eastern European Upper Palaeolithic. (Abstract.) Proceedings of the European Society for the Study of Human Evolution 7:174.

Sinitsyn AA, Hoffecker JF. 2006. Radiocarbon dating and chronology of the Early Upper Paleolithic at Kostenki. Quaternary International 152(3):164-174.

Sinitsyn AA, Praslov ND, Svezhentsev YS, Sulerzhitskiy LD. 1997. Radiouglerodnaia khronologiia verkhnego paleolita vostochnoi Evropy. In: Sinitsyn AA, Praslov ND, editors. Radiouglerodnaia Khronologiia Paleolita Vostochnoi Evropy i Severnoi Azii: Problemy i Perspektivy. Saint Petersburg: AkademPrint. p. 21-66. In Russian.

Stepanchuk VN. 2013. Mira: Early Upper Paleolithic Site in the Dnieper Valley. Stratum plus 1:3-94. In Russian.

Velichko AA, Pisareva VV, Sedov SN, Sinitsyn AA, Timireva SN. 2009. Paleogeography of Kostenki 14 (Markina gora). Archaeology, Ethnology and Anthropology of Eurasia 37:35-50.

Zaretskaya NE, Gavrilov KN, Panin AV, Nechushkin RI. 2018. Geochronological data and the archaeological ideas about the duration of the major Eastern Gravettian sites on the Russian Plain. Rossiiskaya arkheologiya 1:3-16. In Russian.

Zheltova MN. 2008. Kostenkovskie stoianki pervoi nadpoimennoi terrasy: varianty adaptatsii $\mathrm{k}$ okruzhaiushchei srede verkhnego pleistotsena. In Khlopachev GA, editor. Problemy biologicheskoi i kul'turnoi adaptatsii chelovecheskikh populiatsii. Tom 1: Arkheologiia: Adaptatsionnye strategii drevnego naseleniia Severnoi Evrazii: syr'e i priemy obrabotki. Saint Petersburg: Nauka. p. 48-52. In Russian.

Zheltova MN, Zaretskaya NE. 2018. Novyye dannyye po khronostratigrafii Kostenok 1, sloi I. Zapiski IIMK RAN 17:37-44. In Russian. 


\section{APPENDIX}

Previous radiocarbon dates for Kostenki 15, Kostenki 1 Layer I and Kostenki 21 Layer III.

\begin{tabular}{|c|c|c|c|c|c|c|}
\hline Site, layer & Square/context & Sample & Lab code & $\begin{array}{l}\text { Conventional } \\
{ }^{14} \mathrm{C} \text { age }(\mathrm{BP})\end{array}$ & Reference & Notes \\
\hline Kostenki 15 & 1952 excavation & Bone & SPb-663 & $16,895 \pm 200$ & $\begin{array}{l}\text { Khlopachev } \\
2016\end{array}$ & \\
\hline Kostenki 15 & - & Bone & LE-1430 & $21,720 \pm 570$ & $\begin{array}{l}\text { Sinitsyn et al. } \\
1997\end{array}$ & \\
\hline Kostenki 15 & "Dwelling" & Bovid bone & GIN -8020 & $25,700 \pm 250$ & $\begin{array}{l}\text { Sinitsyn et al. } \\
1997\end{array}$ & \\
\hline $\begin{array}{c}\text { Kostenki 1, } \\
\text { Layer I }\end{array}$ & - & Burned bone & LE-450 & $8700 \pm 270$ & $\begin{array}{l}\text { Anikovich et al. } \\
2008\end{array}$ & \\
\hline $\begin{array}{l}\text { Kostenki 1, } \\
\text { Layer I }\end{array}$ & - & Bone & LE-1403 & $10,390 \pm 100$ & $\begin{array}{l}\text { Anikovich et al. } \\
2008\end{array}$ & \\
\hline $\begin{array}{l}\text { Kostenki 1, } \\
\text { Layer I }\end{array}$ & - & Burned bone & GIN-86 & $14,020 \pm 60$ & $\begin{array}{l}\text { Sinitsyn et al. } \\
1997\end{array}$ & \\
\hline $\begin{array}{l}\text { Kostenki 1, } \\
\text { Layer I }\end{array}$ & Dwelling pit "A" & Burned bone & LE-1402 & $16,350 \pm 150$ & $\begin{array}{l}\text { Sinitsyn et al. } \\
1997\end{array}$ & \\
\hline $\begin{array}{l}\text { Kostenki 1, } \\
\text { Layer I }\end{array}$ & Dwelling pit "A" & Burned bone & $?$ & $17,900 \pm 150$ & $\begin{array}{l}\text { Sinitsyn et al. } \\
1997\end{array}$ & \\
\hline $\begin{array}{l}\text { Kostenki } 1, \\
\text { Layer I }\end{array}$ & & Ivory & $?$ & $16,410 \pm 150$ & $\begin{array}{l}\text { Sinitsyn et al. } \\
1997\end{array}$ & \\
\hline $\begin{array}{l}\text { Kostenki } 1, \\
\text { Layer I }\end{array}$ & - & Burned bone & LE-3280 & $18,230 \pm 620$ & $\begin{array}{l}\text { Sinitsyn et al. } \\
1997\end{array}$ & \\
\hline $\begin{array}{l}\text { Kostenki 1, } \\
\text { Layer I }\end{array}$ & Sq. П-70 & Mammoth tooth & LE-4351 & $18,400 \pm 3300$ & $\begin{array}{c}\text { Sinitsyn et al. } \\
1997\end{array}$ & \\
\hline $\begin{array}{l}\text { Kostenki 1, } \\
\text { Layer I }\end{array}$ & $\begin{array}{l}\text { "Storage pit," sq. } \\
\text { ПР-72 }\end{array}$ & Mammoth tooth & LE-2950 & $19,010 \pm 120$ & $\begin{array}{l}\text { Sinitsyn et al. } \\
1997\end{array}$ & \\
\hline $\begin{array}{l}\text { Kostenki 1, } \\
\text { Layer I }\end{array}$ & Pit, sq. H-76 & Burned bone & LE-3292 & $19,540 \pm 580$ & $\begin{array}{l}\text { Sinitsyn et al. } \\
1997\end{array}$ & \\
\hline $\begin{array}{l}\text { Kostenki 1, } \\
\text { Layer I }\end{array}$ & Sq. O-78 & Burned bone & LE-3281 & $19,620 \pm 460$ & $\begin{array}{l}\text { Sinitsyn et al. } \\
1997\end{array}$ & \\
\hline $\begin{array}{l}\text { Kostenki 1, } \\
\text { Layer I }\end{array}$ & - & Mammoth tooth & LE-2949 & $19,860 \pm 200$ & $\begin{array}{l}\text { Sinitsyn et al. } \\
1997\end{array}$ & \\
\hline $\begin{array}{l}\text { Kostenki } 1 \text {, } \\
\text { Layer I }\end{array}$ & - & Burned bone & LE-3277 & $20,100 \pm 680$ & $\begin{array}{l}\text { Sinitsyn et al. } \\
1997\end{array}$ & \\
\hline $\begin{array}{l}\text { Kostenki } 1, \\
\text { Layer I }\end{array}$ & - & Burned bone & AA- 4800 & $20,315 \pm 200$ & $\begin{array}{l}\text { Sinitsyn et al. } \\
1997\end{array}$ & \\
\hline $\begin{array}{l}\text { Kostenki 1, } \\
\text { Layer I }\end{array}$ & - & Burned bone & AA-4799 & $20,855 \pm 260$ & $\begin{array}{l}\text { Sinitsyn et al. } \\
1997\end{array}$ & \\
\hline $\begin{array}{l}\text { Kostenki 1, } \\
\text { Layer I }\end{array}$ & Pit, sq. O-73,74 & Burned bone & GIN- 4851 & $20,800 \pm 300$ & $\begin{array}{l}\text { Sinitsyn et al. } \\
1997\end{array}$ & \\
\hline $\begin{array}{l}\text { Kostenki 1, } \\
\text { Layer I }\end{array}$ & $\begin{array}{l}\text { Pit, sq. } \Pi-74, \text { ash } \\
\text { lens above } \\
\text { ochre horizon, } \\
1986 \\
\text { excavation }\end{array}$ & Burned bone & GIN-4892 & $20,850 \pm 160$ & $\begin{array}{l}\text { Zheltova and } \\
\text { Zaretskaya } \\
2018\end{array}$ & \\
\hline $\begin{array}{l}\text { Kostenki 1, } \\
\text { Layer I }\end{array}$ & Sq. P-78 & Burned bone & GrN-17120 & $20,950 \pm 100$ & $\begin{array}{l}\text { Sinitsyn et al. } \\
1997\end{array}$ & \\
\hline $\begin{array}{l}\text { Kostenki 1, } \\
\text { Layer I }\end{array}$ & Pit, sq. P-73 & Burned bone & GIN-4231 & $21,150 \pm 200$ & $\begin{array}{l}\text { Sinitsyn et al. } \\
1997\end{array}$ & \\
\hline $\begin{array}{l}\text { Kostenki 1, } \\
\text { Layer I }\end{array}$ & Hearth, sq. H-79 & Burned bone & GrN-17119 & $21,180 \pm 100$ & $\begin{array}{l}\text { Sinitsyn et al. } \\
1997\end{array}$ & \\
\hline $\begin{array}{l}\text { Kostenki 1, } \\
\text { Layer I }\end{array}$ & Excavation 1982 & Mammoth rib & $\mathrm{SPb}-672$ & $21,200 \pm 200$ & $\begin{array}{l}\text { Khlopachev } \\
2016\end{array}$ & \\
\hline
\end{tabular}




\section{(Continued)}

\begin{tabular}{|c|c|c|c|c|c|c|}
\hline Site, layer & Square/context & Sample & Lab code & $\begin{array}{l}\text { Conventional } \\
{ }^{14} \mathrm{C} \text { age }(\mathrm{BP})\end{array}$ & Reference & Notes \\
\hline $\begin{array}{c}\text { Kostenki 1, } \\
\text { Layer I }\end{array}$ & $\begin{array}{l}\text { Pit, sq. П-74, } \\
\text { lower part of } \\
\text { fill, } 1986 \\
\text { excavation }\end{array}$ & Burned bone & GIN-4896 & $21,200 \pm 100$ & $\begin{array}{l}\text { Zheltova and } \\
\text { Zaretskaya } \\
2018\end{array}$ & \\
\hline $\begin{array}{c}\text { Kostenki 1, } \\
\text { Layer I }\end{array}$ & $\begin{array}{l}\text { Pit, sq. } \Pi-74, \\
\text { middle part of } \\
\text { fill, } 1986 \\
\text { excavation }\end{array}$ & Burned bone & GIN-4904 & $21,210 \pm 150$ & $\begin{array}{l}\text { Zheltova and } \\
\text { Zaretskaya } \\
2018\end{array}$ & \\
\hline $\begin{array}{l}\text { Kostenki 1, } \\
\text { Layer I }\end{array}$ & $\begin{array}{l}\text { Dwelling pit } \\
\text { "A," base of } \\
\text { nothern } \\
\text { chamber }\end{array}$ & Burned bone & GIN-2534 & $21,300 \pm 400$ & $\begin{array}{l}\text { Sinitsyn et al. } \\
1997\end{array}$ & \\
\hline $\begin{array}{c}\text { Kostenki 1, } \\
\text { Layer I }\end{array}$ & $\begin{array}{l}\text { Pit, sq. HO- } \\
74,75,1986 \\
\text { excavation }\end{array}$ & Burned bone & GIN-4890 & $21,600 \pm 90$ & $\begin{array}{l}\text { Zheltova and } \\
\text { Zaretskaya } \\
2018\end{array}$ & \\
\hline $\begin{array}{l}\text { Kostenki 1, } \\
\text { Layer I }\end{array}$ & Sq. Л-77 & Mammoth tooth & LE-3279 & $21,680 \pm 700$ & $\begin{array}{l}\text { Sinitsyn et al. } \\
1997\end{array}$ & \\
\hline $\begin{array}{l}\text { Kostenki 1, } \\
\text { Layer I }\end{array}$ & $\begin{array}{l}\text { Hearth, sq. HO- } \\
72,73\end{array}$ & Burned bone & GIN-4230 & $21,800 \pm 300$ & $\begin{array}{c}\text { Sinitsyn et al. } \\
1997\end{array}$ & \\
\hline $\begin{array}{c}\text { Kostenki 1, } \\
\text { Layer I }\end{array}$ & $\begin{array}{l}\text { Dwelling pit } \\
\text { ТУФХ-72-75, } \\
\text { “polar fox } \\
\text { layer," } 1986 \\
\text { excavation }\end{array}$ & Burned bone & GIN-4901 & $21,880 \pm 200$ & $\begin{array}{l}\text { Zheltova and } \\
\text { Zaretskaya } \\
2018\end{array}$ & \\
\hline $\begin{array}{c}\text { Kostenki 1, } \\
\text { Layer I }\end{array}$ & - & Mammoth tooth & GIN-8041 & $22,000 \pm 300$ & $\begin{array}{l}\text { Sinitsyn et al. } \\
1997\end{array}$ & $\begin{array}{l}\text { Error in } \\
\text { Sinitsyn } \\
\text { et al. } \\
\text { 1997: } \\
\text { clarified } \\
\text { in GIN } \\
\text { journal }\end{array}$ \\
\hline $\begin{array}{c}\text { Kostenki 1, } \\
\text { Layer I }\end{array}$ & $\begin{array}{l}\text { Storage pit, sq. } \\
\text { K-78 }\end{array}$ & Mammoth tooth & LE-3282 & $22,020 \pm 310$ & $\begin{array}{l}\text { Sinitsyn et al. } \\
1997\end{array}$ & \\
\hline $\begin{array}{l}\text { Kostenki 1, } \\
\text { Layer I }\end{array}$ & Sq. П-76 & Bone & LE-3290 & $22,060 \pm 500$ & $\begin{array}{c}\text { Sinitsyn et al. } \\
1997\end{array}$ & \\
\hline $\begin{array}{l}\text { Kostenki 1, } \\
\text { Layer I }\end{array}$ & $\begin{array}{l}\text { Depression, sq. } \\
\Pi-74,1986 \\
\text { excavation }\end{array}$ & Burned bone & GIN-4895 & $22,175 \pm 260$ & $\begin{array}{l}\text { Zheltova and } \\
\text { Zaretskaya } \\
2018\end{array}$ & \\
\hline $\begin{array}{l}\text { Kostenki 1, } \\
\text { Layer I }\end{array}$ & Pit ВГД-65-67 & Burned bone & GIN-3634 & $22,200 \pm 300$ & $\begin{array}{c}\text { Sinitsyn et al. } \\
1997\end{array}$ & \\
\hline $\begin{array}{l}\text { Kostenki 1, } \\
\text { Layer I }\end{array}$ & $\begin{array}{l}\text { Dwelling pit } \\
\text { ТУФХ-72-75 }\end{array}$ & Burned bone & GIN-4903 & $22,200 \pm 500$ & $\begin{array}{c}\text { Sinitsyn et al. } \\
1997\end{array}$ & \\
\hline $\begin{array}{c}\text { Kostenki 1, } \\
\text { Layer I }\end{array}$ & $\begin{array}{l}\text { Dwelling pit } \\
\text { "A," central } \\
\text { chamber }\end{array}$ & Burned bone & GIN-2533 & $22,300 \pm 200$ & $\begin{array}{l}\text { Sinitsyn et al. } \\
1997\end{array}$ & \\
\hline $\begin{array}{c}\text { Kostenki 1, } \\
\text { Layer I }\end{array}$ & Sq. ИМ-5-6 & Burned bone & GIN-1870 & $22,300 \pm 230$ & $\begin{array}{l}\text { Sinitsyn et al. } \\
1997\end{array}$ & \\
\hline $\begin{array}{l}\text { Kostenki 1, } \\
\text { Layer I }\end{array}$ & Hearth, sq. H-79 & Charcoal & GrN-17118 & $22,330 \pm 150$ & $\begin{array}{c}\text { Sinitsyn et al. } \\
1997\end{array}$ & \\
\hline $\begin{array}{l}\text { Kostenki 1, } \\
\text { Layer I }\end{array}$ & Sq. П-69 & Mammoth tooth & GIN-6249 & $22,600 \pm 300$ & $\begin{array}{c}\text { Sinitsyn et al. } \\
1997\end{array}$ & \\
\hline $\begin{array}{l}\text { Kostenki 1, } \\
\text { Layer I }\end{array}$ & Hearth, sq. H-62 & Burned bone & GIN-3633 & $22,600 \pm 300$ & $\begin{array}{l}\text { Sinitsyn et al. } \\
1997\end{array}$ & \\
\hline $\begin{array}{c}\text { Kostenki 1, } \\
\text { Layer I }\end{array}$ & - & Mammoth tooth & LE-2969 & $22,700 \pm 250$ & $\begin{array}{c}\text { Sinitsyn et al. } \\
1997\end{array}$ & \\
\hline
\end{tabular}




\section{(Continued)}

\begin{tabular}{|c|c|c|c|c|c|c|}
\hline Site, layer & Square/context & Sample & Lab code & $\begin{array}{l}\text { Conventional } \\
{ }^{14} \mathrm{C} \text { age (BP) }\end{array}$ & Reference & Notes \\
\hline $\begin{array}{l}\text { Kostenki 1, } \\
\text { Layer I }\end{array}$ & Sq. Ж-70 & Mammoth tooth & LE-2800 & $22,760 \pm 250$ & $\begin{array}{c}\text { Sinitsyn et al. } \\
1997\end{array}$ & \\
\hline $\begin{array}{l}\text { Kostenki 1, } \\
\text { Layer I }\end{array}$ & $\begin{array}{l}\text { Dwelling pit } \\
\text { "Ж”" }\end{array}$ & Burned bone & GIN-2530 & $22,800 \pm 200$ & $\begin{array}{c}\text { Sinitsyn et al. } \\
1997\end{array}$ & \\
\hline $\begin{array}{l}\text { Kostenki 1, } \\
\text { Layer I }\end{array}$ & Dwelling pit "A" & Burned bone & GIN-3632 & $22,800 \pm 300$ & $\begin{array}{l}\text { Sinitsyn et al. } \\
1997\end{array}$ & \\
\hline $\begin{array}{c}\text { Kostenki 1, } \\
\text { Layer I }\end{array}$ & $\begin{array}{l}\text { Dwelling pit } \\
\text { "A", central } \\
\text { chamber }\end{array}$ & Burned bone & GIN-2528 & $23,000 \pm 500$ & $\begin{array}{l}\text { Sinitsyn et al. } \\
1997\end{array}$ & \\
\hline $\begin{array}{c}\text { Kostenki 1, } \\
\text { Layer I }\end{array}$ & Sq. Л-78 & Mammoth tooth & LE-3276 & $23,010 \pm 300$ & $\begin{array}{c}\text { Sinitsyn et al. } \\
1997\end{array}$ & \\
\hline $\begin{array}{l}\text { Kostenki 1, } \\
\text { Layer I }\end{array}$ & $\begin{array}{l}\text { Dwelling pit } \\
\text { ТУФХ-72-75 }\end{array}$ & Mammoth tooth & LE-3289 & $23,260 \pm 680$ & $\begin{array}{c}\text { Sinitsyn et al. } \\
1997\end{array}$ & \\
\hline $\begin{array}{l}\text { Kostenki 1, } \\
\text { Layer I }\end{array}$ & $\begin{array}{l}\text { Dwelling pit } \\
\text { ТУФХ -72-75 }\end{array}$ & Burned bone & LE-3286 & $23,490 \pm 420$ & $\begin{array}{c}\text { Sinitsyn et al. } \\
1997\end{array}$ & \\
\hline $\begin{array}{l}\text { Kostenki 1, } \\
\text { Layer I }\end{array}$ & $\begin{array}{l}\text { Dwelling pit } \\
\text { "A,” central } \\
\text { chamber }\end{array}$ & Burned bone & GIN-2527 & $23,500 \pm 200$ & $\begin{array}{l}\text { Sinitsyn et al. } \\
1997\end{array}$ & \\
\hline $\begin{array}{l}\text { Kostenki 1, } \\
\text { Layer I }\end{array}$ & $\begin{array}{l}\text { Dwelling pit } \\
\text { ЕЖ3-72-74, } \\
\text { base }\end{array}$ & Charcoal & GrA-5244 & $\begin{array}{c}23,600 \pm 410 / \\
400\end{array}$ & $\begin{array}{l}\text { Sinitsyn et al. } \\
1997\end{array}$ & \\
\hline $\begin{array}{l}\text { Kostenki 1, } \\
\text { Layer I }\end{array}$ & Pit, sq. K-78 & Mammoth ivory & LE-3283 & $23,640 \pm 320$ & $\begin{array}{c}\text { Sinitsyn et al. } \\
1997\end{array}$ & \\
\hline $\begin{array}{c}\text { Kostenki 1, } \\
\text { Layer I }\end{array}$ & $\begin{array}{l}\text { Dwelling pit } \\
\text { ТУФХ-72-75 }\end{array}$ & Mammoth tooth & LE -2951 & $23,770 \pm 200$ & $\begin{array}{c}\text { Sinitsyn et al. } \\
1997\end{array}$ & \\
\hline $\begin{array}{l}\text { Kostenki 1, } \\
\text { Layer I }\end{array}$ & Pit, sq. П-74 & Charcoal & GrA-5243 & $\begin{array}{c}24,030 \pm 440 / \\
410\end{array}$ & $\begin{array}{c}\text { Sinitsyn et al. } \\
1997\end{array}$ & \\
\hline $\begin{array}{c}\text { Kostenki 1, } \\
\text { Layer I }\end{array}$ & Dwelling pit " 3 " & Burned bone & GIN-2529 & $24,100 \pm 500$ & $\begin{array}{l}\text { Sinitsyn et al. } \\
1997\end{array}$ & \\
\hline $\begin{array}{l}\text { Kostenki 1, } \\
\text { Layer I }\end{array}$ & Dwelling pit " И" & $\begin{array}{l}\text { Mammoth tooth } \\
\text { fragments }\end{array}$ & LE-4352 & $24,570 \pm 3930$ & $\begin{array}{c}\text { Sinitsyn et al. } \\
1997\end{array}$ & \\
\hline $\begin{array}{c}\text { Kostenki 1, } \\
\text { Layer I }\end{array}$ & $\begin{array}{l}\text { Feature with } \\
\text { "wall" }\end{array}$ & $?$ & LE-2801 & $\begin{array}{c}25,600 \pm \\
2,310\end{array}$ & $\begin{array}{l}\text { Sinitsyn et al. } \\
1997\end{array}$ & $\begin{array}{l}\text { Error in } \\
\text { Sinitsyn } \\
\text { et al. } \\
\text { 1997: } \\
\text { clarified } \\
\text { in LE } \\
\text { journal }\end{array}$ \\
\hline $\begin{array}{c}\text { Kostenki 21, } \\
\text { Layer III }\end{array}$ & & Charcoal & LE-1043 & $16,960 \pm 300$ & $\begin{array}{l}\text { Sinitsyn et al. } \\
1997\end{array}$ & $\begin{array}{l}\text { Same } \\
\text { sample as } \\
\text { GrN- } \\
7363\end{array}$ \\
\hline $\begin{array}{c}\text { Kostenki 21, } \\
\text { Layer III }\end{array}$ & & Charcoal & GrN-7363 & $22,270 \pm 150$ & $\begin{array}{l}\text { Sinitsyn et al. } \\
1997\end{array}$ & $\begin{array}{l}\text { Same } \\
\text { sample as } \\
\text { LE-1043 }\end{array}$ \\
\hline $\begin{array}{c}\text { Kostenki 21, } \\
\text { Layer III }\end{array}$ & & Charcoal & GrN-10513 & $21,260 \pm 340$ & $\begin{array}{c}\text { Sinitsyn et al. } \\
1997\end{array}$ & \\
\hline $\begin{array}{l}\text { Kostenki 21, } \\
\text { Layer III }\end{array}$ & & Charcoal & GrN-14669 & $22,230 \pm 100$ & Zheltova 2008 & \\
\hline $\begin{array}{c}\text { Kostenki 21, } \\
\text { Layer III }\end{array}$ & & Charcoal & GrN-24968 & $22,860 \pm 320$ & Zheltova 2008 & \\
\hline
\end{tabular}

